\title{
School Banking: A New Idea of Banking Operation in Bangladesh
}

\author{
Ujjal Mondal ${ }^{1}$, Md. Solaiman Hossain ${ }^{2}$, Md. Abdul Mannan Khan ${ }^{3}$ \\ ${ }^{1,2}$ Lecturer, Department of Accounting and Information Systems, Bangabandhu Sheikh Mujibur Rahman Science and Technology \\ University, Gopalganj-8100, Bangladesh
}

${ }^{3}$ Assistant Professor, Department of Accounting and Information Systems, Bangabandhu Sheikh Mujibur Rahman Science and Technology University, Gopalganj-8100, Bangladesh, India

\begin{abstract}
This paper mainly focuses on the present scenario of school banking policy practiced by scheduled banks in Bangladesh. The study is mainly based on secondary data highlighting the school banking policy formulation and governance as well as different school banking activities such as account opening and deposit collection by State-owned Commercial Banks (SCBs), Specialized Development Banks (SDBs), Private Commercial Banks (PCBs), Foreign Commercial Banks (FCBs) and new banks (Scheduled in 2013). School banking practices in Bangladesh is passing through an introductory level. But banks are trying to go for the boost of school banking. In 2014, banks have created 8,50,303 accounts and collected Tk. 7,175 million under school banking scheme. On which, PCBs have opened $65 \%$ accounts and gathered 73\% deposit of total school banking operation in Bangladesh. SCBs and SDBs are trying to create more accounts and to collect more money on this scheme. But FCBs haven't played a significant role on school banking. So practicing school banking policy in Bangladesh is not in a satisfactory condition, but it is a positive sign that Bangladesh Bank has already developed a policy guideline to promote school banking. It is an urgent duty to all banks and responsible authorities along with general people to come forward to take necessary steps about school banking so that in near future banks can take all school going children under banking systems and ensure smooth school banking operation in Bangladesh.
\end{abstract}

Keywords: School, Bank, School Banking, Accounts, Deposit, SCBs, SDBs, PCBs, FCBs etc.

\section{Back-Drop}

School banking is one type of banking wing towards school going students and their parents to facilitate lower depository obligation, free from operating charges, higher rate of interest on deposit with advanced form of banking transactions. It is not new in Bangladesh. Some banks, including Muslim Bank, had introduced that type of banking program in the 1960s, before the liberation of Bangladesh, but it was not last long. It was some years earlier AB bank (formerly Arab Bangladesh Bank) launched the service in Sunshine Grammar School in Chittagong in 2003, but that too did not work. Finally, school banking got renewed impetus when Bangladesh Bank, central bank of Bangladesh, issued the formal circular to all scheduled banks on November 02, 2010. The core objective of school banking is development of banking sector as a model of financial inclusion by introducing banking operation and advanced technology among school going students as well as participating students into economic development by the mode of savings. Now, moreover all scheduled banks are conducting their school banking operation and already they have introduced 850,303 accounts and collected Tk. 717.49 crore under school banking scheme. So, school banking would be a smart form of banking activities and it would gather all school going students in Bangladesh under a uniform banking facilities.

\section{Objectives of the Study}

The prime objective of the study is to analyze the practices of School Banking in Bangladesh from different viewpoint. The other specific objectives of the study are to give some suggestions to promote school banking policies and guidelines among the beneficiaries and banking sector in Bangladesh.

\section{Methodology and Limitation of the Study}

The paper is produced only based on secondary sources of data from review report of Bangladesh Bank and annual reports of different commercial banks in Bangladesh. In addition to this, the data is also collected through a range of company's corporate profile, daily newspapers, different journals and articles etc. The data are analyzed in aspect of practices and problems of school banking. Actually the author did not go through the physical interview of bank executives for conducting the study. The findings of the study are reliable as the sources of data authentic. So absence of primary data involvement is the major limitation of the study. Along with, there is a scarcity of related literature and the author rarely found any research article on this topic besides some reports on newspapers.

\section{Review of Literature}

Jahidul Alom (2015) elucidated that school banking brings students under banking services so that they can start savings, involve in banking activities and participate and contribute in economic activities through savings. He also focused a statistical data about number of accounts and amount of money deposited in many banks (rural and urban areas) under school banking scheme. He also strongly believed that very soon school banking would be part and parcel in regular banking services.

Mohammed Mosroor Hossen (2012) described that banks have introduced different types of products with the customers to strike up their deposit for the sake of increasing bank business and motivating customers to be introduced to build up their capital to guard imminent miseries of the destruction. School Banking Scheme is a new separate 


\section{International Journal of Science and Research (IJSR) \\ ISSN (Online): 2319-7064}

Index Copernicus Value (2013): 6.14 | Impact Factor (2014): 5.611

product but it is becoming more popular with a view to inspiring for savings and creating savings mentality to the school going student with an attractive interest rate. By this scheme most of the students can able to raise capital for their future and besides this bank not only uses to recurring deposit but also play a social role in the country. But, due to lack in publicity school banking scheme did not overcome its objectives like other deposit scheme.

Mohammad Ali (2012) tried to explore school banking activities in Bangladeshi commercial banks by the responses of high level officials of different banks. He summarized the causes of popularity of school banking among the people due mainly to its some particular features including safe deposit and insurance coverage for their children and intimating the students with banking habit from early age. Some officials mentioned the more the days are passing, the more the banks are getting tremendous responses from the customers regarding school banking. But some officials shared bitter experience about school banking. They pointed two basic reasons behind the poor response: instead of opening separate account for the school level students, their parents are more interested to open joint account with their children; school headmasters normally didn't issue certificate required for opening school banking account and the banks also reluctant to open such account by depositing of only Tk. 100-200.

Sajjadur Rahman (2011) focused the background of school banking in our country. He noted that students need to be brought under banking services to help them contribute to economic activities through savings. He mentioned school banking operations by different banks in their distinctive name and also found out the present scenario of this. He concluded that banks do not see school banking as a profit making business, but they are hope that many of these students would become their customers in future.

\section{Background of the Study}

\section{Conceptual Definition:}

School: A place where children go to be educated (Oxford Advanced Learner's Dictionary, Eighth edition 2010: 1356).

Bank: An organization that provides various financial services, for example keeping and lending money (Oxford Advanced Learner's Dictionary, Eighth edition 2010: 104); a commercial institution licensed as a taker of deposits. Banks are concerned mainly with making and receiving payments on behalf of their customers, accepting deposits, and making short-term loans to private individuals, companies, and other organizations (Oxford Dictionary of Business, Third edition 2002: 46); a bank is a financial intermediary that accepts deposits and channels those deposits into lending activities, either directly by loaning or indirectly through capital markets (Wikipedia); bank is a financial institution that collects society's surplus cash and gives a part of that as loan to investors for earning profit (A. R Khan, 2009:1).

Banking: The activities undertaken by banks, this includes personal banking (non-business customers), commercial banking (small and medium-sized business customers), and corporate banking (large international and multinational corporations) (Oxford Dictionary of Business, Third edition 2002: 48).

School Banking: School banking account is a savings deposit account heading with the name of student and to be operated jointly in collaboration with guardian's signature who can be the nominee of the account (Mohammed Mosroor Hossen, 2012). So, it is a special type of banking towards the school going children and their parents to know about the banking systems that helps to make a habit of savings from the early age of children. This is a new form of banking that is getting more popular day by day because of some smart advantages, such as free of charges and fees, free internet banking, a waiver of minimum balance requirement, facility of debit card at lower cost, etc. School banking scheme helps students and parents with a sizeable amount of savings after a certain period and it also aims to insist the habit of savings into the students (Sajjadur Rahman, 2011).

Policy Formulation and Governance: The concept of school banking is not well known in Bangladesh, but it is becoming more popular among the all scheduled banks. To expand its boundary and for having vast importance of it, Bangladesh Bank advised all scheduled banks to introduce school banking in their operations by BPRD Circular Letter No. 12 on November 02, 2010. Through the GBCASRD Circular No. 07 on October 28, 2013, Bangladesh Bank issued an order to all banks operated in Bangladesh to submit their respective school banking activities report to the central bank in a quarterly basis. To reach banking services to the students in an appropriate manner through ensuring more transparency, awareness and acceleration into this activity, Bangladesh Bank has issued some guidelines on operation of School Banking to all scheduled banks for their compliance.

1) Opening of Account: To open an account under School Banking Operation the age of the students would be six years to below eighteen years.

2) Operation of Account: Father/mother or legal guardian of the students will be able to operate School Banking accounts.

3) Account Opening Form: Existing Uniform Account Opening Form and KYC Form will be used to open School Banking accounts and instructions issued vide Circular Letter no. AMLD-1(policy)/2008-2324, dated June 30, 2008 of Bangladesh Financial Intelligence Unit will be applicable. For such accounts, both Guardian and student have to fill up Personal Information part of Account Opening Form and both forms must be signed by the legal guardian.

4) Nature of Account: Normally School Banking accounts will be opened as Savings Account. But, if necessary, any type saving schemes can be opened by transferring balance from these accounts.

5) Minimum Initial Deposit: Minimum initial deposit for such accounts will be Tk. 100/- (one hundred).

6) Nationality: Both the account holder and Guardian/Legal Guardian will be citizen of Bangladesh.

7) Required Documents to Open Account: Proper KYC of both the account holder and account operator must be ensured. In this context, the attested photocopies of birth registration certificate and institutional identity 


\section{International Journal of Science and Research (IJSR) \\ ISSN (Online): 2319-7064}

Index Copernicus Value (2013): 6.14 | Impact Factor (2014): 5.611

card/certificates issued by Educational Institute/receipt of school fees of latest month of students have to be collected by bank. All these documents must be preserved in the bank.

8) Source of Fund of Account Holder: The sources of fund in this account must be verified and related transactions must be rational in this respect.

9) ATM Card: ATM card (only debit card) can be issued against this type of account. Monthly withdrawal limit through ATM Card and Point of Sales (POS) will be maximum Tk. 2000/-. This limit may be increased up to Tk. 5000/- on request of the Guardian. In case of every transaction taken place, transaction details will be automatically sent through SMS Transaction Alert to the account holder's guardian's mobile number.

10) Service Charge/Fee: School Banking accounts will be free of service charge or fee except government fees. ATM card issue fee and renewal fee will be considered if ATM card is issued against this form of account.

11) Collection of Fees from Students: Bank can collect monthly tuition fees and other fees from students on behalf of the school authority (by having understanding with such educational institutions) through such type of accounts. Bank will inspire the educational institutions so that all school going students can be brought under school banking.

12) Establishment of School Banking Counter/Desk: Concerned bank branches may establish a separate School Banking Counter/Desk to facilitate school banking activities among students. Bank will provide deposit and withdrawal services along with other banking activities through this counter. Moreover, bank branches may provide these services in one or more fixed date by opening booth in the premises of educational institutions by having their consent.

13) Deposit of scholarship/stipend benefit: All scholarship or stipend of the student can be deposited through school banking accounts. In this regard scholarship or stipend provider government/semigovernment/autonomous/private institutions have to

sign a Memorandum of Understanding with the concerned banks.

14) Education Insurance: Concerned banks can provide education insurance facility in these accounts as such if any student faces financial crisis to meet up their educational expenses due to family/natural causes then, it will be possible to facilitate them under this insurance coverage.

15) Reporting and Disclosure of School Banking Activities: It is obligatory to submit Progress Report (as per enclosed format) of school banking to the Green Banking and CSR Department of Bangladesh Bank in quarterly basis. This report has to be submitted within the 15(fifteen) days of each quarter. Banks will submit their first quarterly report based on December 31, 2014 within 15 January, 2015. Besides this, banks will disclose updated information regarding school banking in their annual report and website.

16) Others:

16.1: Bank will also comply with related acts, rules, regulations and policy guidelines circulated by Bangladesh Bank in case of school banking activities.

16.2: Whenever account holder (student) will turn into 18 (eighteen) years; the account will be transformed into regular savings account with his/her consent and then will be continued. In this regards related rules, regulations, policy guidelines circulated by Bangladesh Bank will be applicable as usual;

Mentionable, in case of converting into savings accounts, full KYC form must be accomplice and other declaration letter with TP must be obtained. After completing eighteen years of account holder and before converting into regular savings account, no withdrawal will be allowed (except account closure) in this period; 16.3: These guidelines will also be applicable for School Banking accounts which have been opened before issuing this circular.

\section{Analysis and Presentation of Data}

Table 1: Numbers of bank accounts under School Banking:

\begin{tabular}{|c|c|c|c|c|c|c|}
\hline Categories of Banks & $\begin{array}{c}\text { Up to Dec. 31, } \\
2012\end{array}$ & $\begin{array}{c}\text { Up to June 30, } \\
2013\end{array}$ & $\begin{array}{c}\text { Up to Dec. 31, } \\
2013\end{array}$ & $\begin{array}{c}\text { Up to June 30, } \\
2014\end{array}$ & $\begin{array}{c}\text { Up to Sep. 30, } \\
2014\end{array}$ & $\begin{array}{c}\text { Up to Dec. 31, } \\
2014\end{array}$ \\
\hline SCBs & 1,961 & 4,270 & 27,156 & 101,468 & $1,37,976$ & $1,66,895$ \\
\hline SDBs & 1,781 & 4,279 & 32,983 & $1,06,503$ & $1,21,572$ & $1,30,799$ \\
\hline PCBs & $1,28,417$ & 215,597 & 235,161 & $4,29,995$ & $5,33,402$ & $5,50,426$ \\
\hline FCBs & 374 & 573 & 495 & 1,210 & 1,258 & 1,269 \\
\hline Scheduled in 2013 & - & - & 7 & 289 & 583 & 914 \\
\hline Total & $1,32,537$ & $2,24,719$ & $2,95,802$ & $6,39,465$ & $7,94,791$ & $8,50,303$ \\
\hline
\end{tabular}

Source: Bangladesh Bank's Quarterly Review Report on School Banking, December 2012-December 2014.

Table 01 shows numbers of bank accounts under school banking on the basis of different categories of bank from December 31, 2012 to December 31, 2014. Up to December 31, 2014, 49 scheduled banks out of total 56 banks (including new 09 scheduled banks) opened a total number of 8.50 lacs school bank accounts that was only 1.32 lacs in December 31, 2012 and 2.95 lacs in December 31, 2013. So it is easily notified that school bank accounts are going to an increasing pattern. Compare with different types of banks, private commercial banks hold large number of school bank accounts which was 5.50 lacs at the end of 31 December,
2014 and it is satisfactory to say, that was passing a growing trend from the preceding periods. State-owned commercial banks and specialized development banks also doing better for opening new school bank accounts experiencing their past records. Out of 09 foreign commercial banks, 08 banks (excluding City Bank N.A) have opened their school banking wing and their total school bank accounts was 1,269 at December, 2014. It is necessary to say, 03 newly scheduled banks in 2013 (out of 09) i.e. Meghna Bank Ltd., NRB Commercial Bank Ltd. and NRB Bank Ltd. have

\section{Volume 4 Issue 11, November 2015}




\section{International Journal of Science and Research (IJSR) \\ ISSN (Online): 2319-7064}

Index Copernicus Value (2013): 6.14 | Impact Factor (2014): 5.611

already opened their school banking activities and they hold

914 accounts in total.

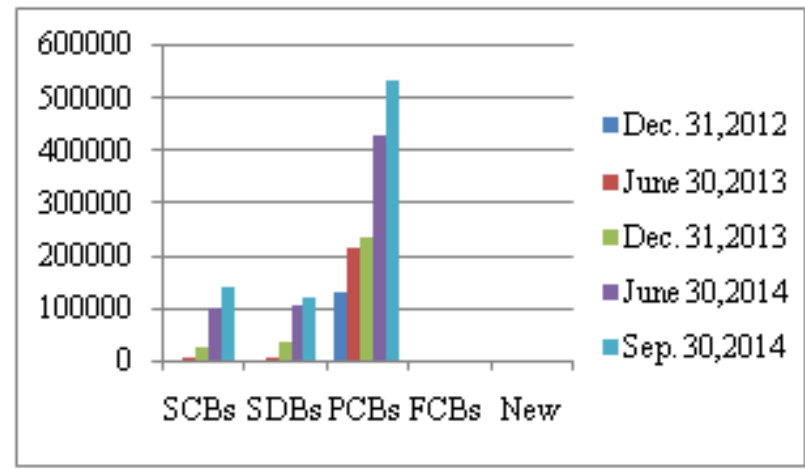

Graph 1: Numbers of bank accounts under School Banking:

Source: Bangladesh Bank’s Quarterly Review Report on School Banking, December 2012-December 2014

Table 2: Amount of money in bank accounts under School Banking:

\begin{tabular}{|c|c|c|c|c|c|c|}
\hline Categories of Banks & $\begin{array}{c}\text { Up to Dec. 31, } \\
\text { 2012(Amount in } \\
\text { Crore Taka) }\end{array}$ & $\begin{array}{c}\text { Up to June 30, } \\
\text { 2013(Amount in } \\
\text { Crore Taka) }\end{array}$ & $\begin{array}{c}\text { Up to Dec. 31, } \\
\text { 2013(Amount in } \\
\text { Crore Taka) }\end{array}$ & $\begin{array}{c}\text { Up to June 30, } \\
\text { 2014(Amount in } \\
\text { Crore Taka) }\end{array}$ & $\begin{array}{c}\text { Up to Sep. 30, } \\
\text { 2014(Amount in } \\
\text { Crore Taka) }\end{array}$ & $\begin{array}{c}\text { Up to Sep. 30, } \\
\text { 2014(Amount in } \\
\text { Crore Taka) }\end{array}$ \\
\hline SCBs & 0.19 & 1.47 & 2.92 & 5.04 & 134.59 & 174.97 \\
\hline SDBs & 0.50 & 1.05 & 3.01 & 6.98 & 8.56 & 11.65 \\
\hline PCBs & 94.91 & 124.33 & 296.93 & 393.07 & 482.66 & 527.13 \\
\hline FCBs & 1.18 & 1.62 & 2.93 & 1.74 & 1.89 & 1.89 \\
\hline Scheduled in 2013 & - & - & 0.0013 & 0.46 & 1.42 & 1.85 \\
\hline Total & 96.51 & 128.47 & 305.79 & 407.29 & 629.12 & 717.49 \\
\hline
\end{tabular}

Source: Bangladesh Bank's Quarterly Review Report on School Banking, December 2012-December 2014.

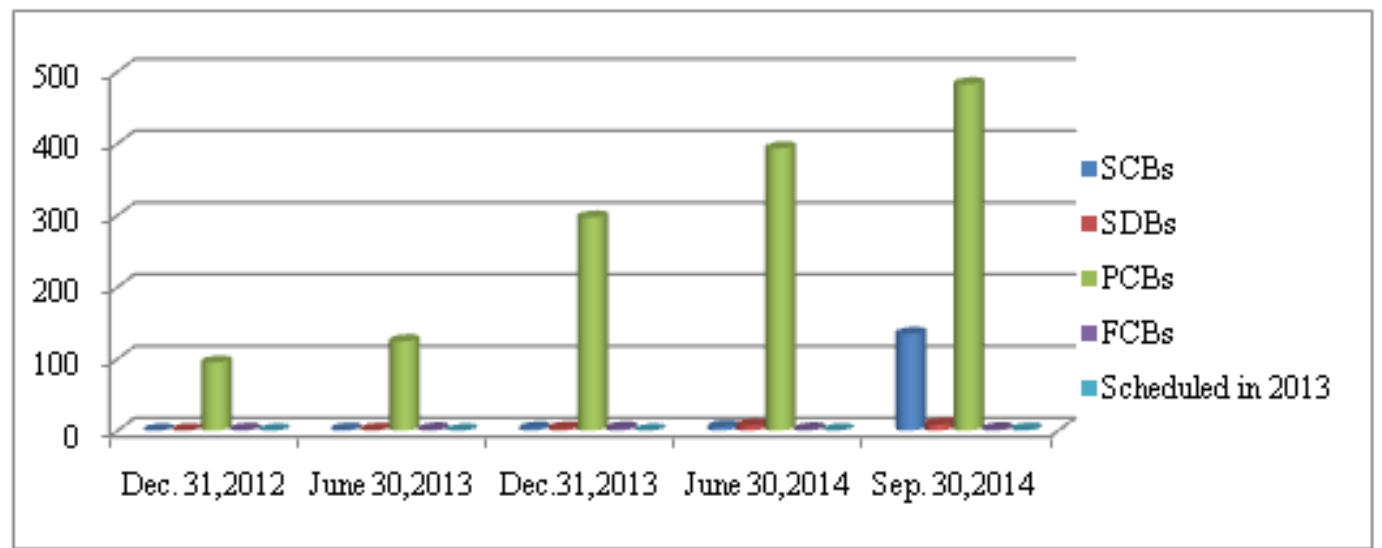

Graph 2: Amount of money in bank accounts under School Banking

Source: Bangladesh Bank's Quarterly Review Report on School Banking, December 2012-December 2014.

Out of 56 scheduled banks in Bangladesh, 49 banks hold total Tk. 717.49 crore in their school banking accounts up to December 31, 2014. At the end of the year 2013 and 2012 deposit amount under school banking was Tk. 305.79 crore and Tk. 96.51 crore respectably. So the increasing trend from the successive period is $217 \%$ in 2013 and $135 \%$ in 2014. Private commercial banks collect more amount of deposit under school banking that is Tk. 527.13 crore at the end of 31 December, 2014. But the increasing rate is more in case of state-owned commercial banks; they hold approximately 60 times more amount of money in 2014 than 2013. On the other hand, specialized development banks hold about 4 times more and private commercial banks hold more or less 1.78 times more money under school bank accounts at the closing period of 2014 than 2013.
Table 3: Highest five banks having large numbers of accounts under School Banking up to December, 2014:

\begin{tabular}{|c|l|c|c|}
\hline Ranking & \multicolumn{1}{|c|}{ Name of the banks } & $\begin{array}{c}\text { Number of } \\
\text { accounts }\end{array}$ & $\begin{array}{c}\text { Percentage of total } \\
\text { accounts (\%) }\end{array}$ \\
\hline 1 & $\begin{array}{l}\text { Islami Bank Bangladesh } \\
\text { Ltd. }\end{array}$ & $1,78,751$ & 21.02 \\
\hline 2 & $\begin{array}{l}\text { Rajshahi Krishi Unnayon } \\
\text { Bank }\end{array}$ & 94,200 & 11.08 \\
\hline 3 & Agrani Bank Ltd. & 90,596 & 10.65 \\
\hline 4 & Uttara Bank Ltd. & 69,084 & 8.12 \\
\hline 5 & Prime Bank Ltd. & 55,159 & 6.49 \\
\hline
\end{tabular}

Source: Bangladesh Bank's Quarterly Review Report on School Banking, December 31, 2014.

Table-03 depicts that the ranking of five successful banks those have large number of accounts under school banking. Islami Bank Bangladesh Ltd. secured the first position having $1,78,751$ account holders, that is $21.02 \%$ of total school bank accounts in all scheduled banks in Bangladesh.

\section{Volume 4 Issue 11, November 2015}




\section{International Journal of Science and Research (IJSR) \\ ISSN (Online): 2319-7064 \\ Index Copernicus Value (2013): 6.14 | Impact Factor (2014): 5.611}

Rajshahi Krishi Unnayan Bank, Agrani Bank Ltd., Uttara Bank Ltd. and Prime Bank Ltd. are the another four successful banks having greater number of school bank accounts; they hold $11.08 \%, 10.65 \%, 8.12 \%$ and $6.49 \%$ of total school banks accounts respectively.

Table 4: Five successful banks having highest deposit under School Banking up to December, 2014:

\begin{tabular}{|c|c|c|c|}
\hline Ranking & Name of the banks & $\begin{array}{c}\text { Deposit (In } \\
\text { crore Tk.) }\end{array}$ & $\begin{array}{c}\text { Percentage of } \\
\text { total deposit (\%) }\end{array}$ \\
\hline 1 & $\begin{array}{c}\text { Dutch Bangla Bank } \\
\text { Ltd. }\end{array}$ & 183.66 & 25.60 \\
\hline 2 & Agrani Bank Ltd. & 159.58 & 22.24 \\
\hline 3 & $\begin{array}{c}\text { Islami Bank } \\
\text { Bangladesh Ltd. }\end{array}$ & 65.14 & 9.08 \\
\hline 4 & Rupali Bank Ltd. & 61.15 & 8.52 \\
\hline 5 & Eastern Bank Ltd. & 60.21 & 8.39 \\
\hline
\end{tabular}

Source: Bangladesh Bank's Quarterly Review Report on School Banking, December 31, 2014.

The table-04 represents five scheduled banks that have collected more amount of money under school banking scheme. In Dutch Bangla Bank Ltd. highest amount of money is deposited under school bank accounts that is Tk. 183.66 crore in amount which is $25.60 \%$ of total money deposited under school banking accounts in all banks. Agrani Bank Ltd. collects Tk. 159.58 crore, Islami Bank Bangladesh Ltd. Tk. 65.14 crore, Rupali Bank Ltd. Tk. 61.15 and Eastern Bank Ltd. Tk. 60.21 under their school banking policy that is $22.24 \%, 9.08 \%, 8.52 \%$ and $8.39 \%$ of total deposit respectively.

\section{Analysis of the Study:}

Practice of school banking in Bangladesh is passing through an increasing trend which has been shown earlier in the study. Banks are conducting school banking activities not only in urban area but also in rural area. Up to December 31, 2014, 49 scheduled banks operated their school banking in rural and urban areas in the ratio of 3:5. From the data analysis it is shown that private commercial banks introduced 5.50 lacs accounts under school banking that is $65 \%$ of total 8.50 lacs accounts in school banking scheme operated by all bank. On the other hand, private commercial banks collected deposit approximately Tk. 527.13 crore that is $73.47 \%$ of total deposit of Tk. 717.49 crore. So, private commercial banks are doing better job in case of school banking compare to other banks that is a positive sign for our banking business. In last quarter in 2014, banks have collected deposit of Tk. 307.43 crore under school banking and they have given withdrawal facilities of Tk. 179.52 crore to the accounts holders from where Tk. 22.39 crore was withdrawn by ATM booth.

In case of account opening Islami Bank Bangladesh Limited opened highest number of accounts under school banking that was $1,78,751$ accounts which was $21.02 \%$ of total school banking accounts operated by all scheduled banks in Bangladesh. It is also noted that Dutch Bangla Bank Limited collected more amount of deposit under school banking that is Tk. 183.66 crore which is $25.60 \%$ of total deposit under that scheme.
Table 5: Numbers of bank accounts under School Banking from December, 2011 to December, 2014:

\begin{tabular}{|c|c|c|c|c|}
\hline Categories of Banks & 2011 & 2012 & 2013 & 2014 \\
\hline SCBs & 354 & 1,961 & 27,156 & $1,66,895$ \\
\hline SDBs & 637 & 1,781 & 32,983 & $1,30,799$ \\
\hline PCBs & 27,830 & $1,28,421$ & $2,35,168$ & $5,51,340$ \\
\hline FCBs & 259 & 374 & 495 & 1,269 \\
\hline Total & 29,080 & $1,32,537$ & $2,95,802$ & $8,50,303$ \\
\hline
\end{tabular}

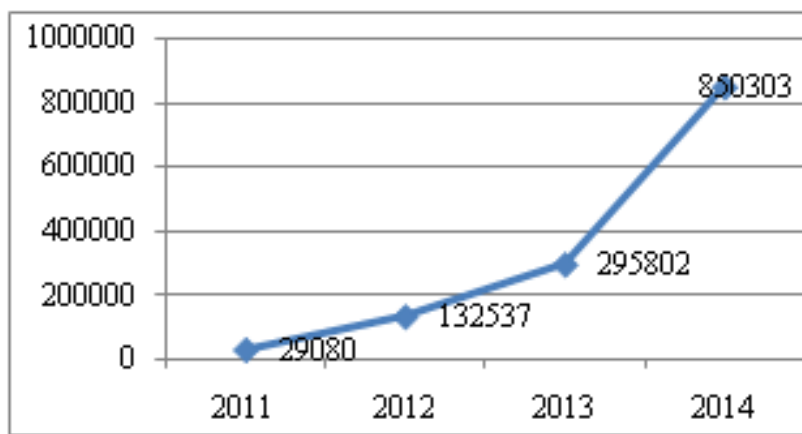

Source: Bangladesh Bank's Quarterly Review Report on School Banking, December 31, 2014.

Table 6: Amount of money deposited under School Banking from December, 2011 to December, 2014:

\begin{tabular}{|c|c|c|c|c|}
\hline Categories of Banks & 2011 & 2012 & 2013 & 2014 \\
\hline SCB & 1.16 & 0.19 & 2.92 & 174.97 \\
\hline SDBs & 0.17 & 0.31 & 3.01 & 11.65 \\
\hline PCBs & 29.04 & 94.93 & 296.93 & 528.98 \\
\hline FCBs & 0.42 & 1.08 & 2.93 & 1.89 \\
\hline Total & 30.79 & 96.51 & 305.79 & 717.49 \\
\hline
\end{tabular}

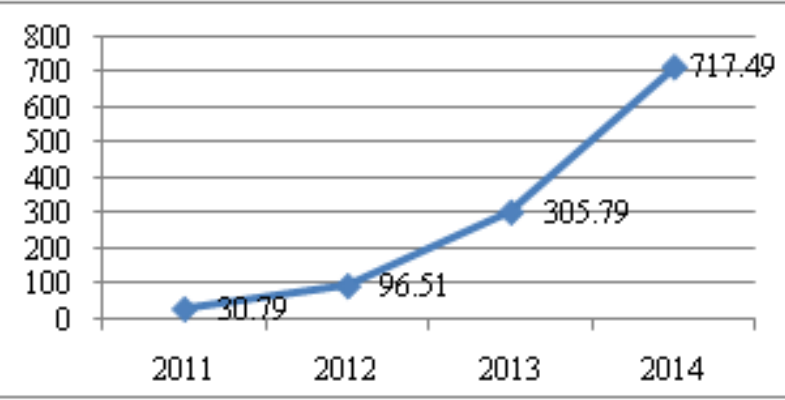

Source: Bangladesh Bank's Quarterly Review Report on School Banking, December 31, 2014.

\section{Specific Findings}

- School banking activities have been introduced in 49 banks.

- 49 banks have prepared their own School Banking Policy.

- 8,50,303 accounts have been opened under school banking scheme of which 3,07,764 accounts in rural area braches and 5,42,539 accounts in town area branches.

- Approximately Tk. 7,175 million has been collected under school banking scheme in 49 banks in Bangladesh.

- Islami Bank Bangladesh Limited has created highest number of bank accounts ( $21 \%$ of total accounts) under this scheme. On the other hand, Dutch Bangla Bank holds maximum number of deposit (Tk. 1,838 million that is $25.60 \%$ of total deposit) under school banking scheme.

- In 2014, number of accounts under school banking has been increased about $287 \%$ that of 2013 and total amount

\section{Volume 4 Issue 11, November 2015}




\section{International Journal of Science and Research (IJSR) \\ ISSN (Online): 2319-7064}

Index Copernicus Value (2013): 6.14 | Impact Factor (2014): 5.611

of deposit under this scheme has also been increased about $235 \%$ that of 2013

\section{Recommendation and Suggestions:}

- Bangladesh Bank should carefully monitor and supervise the school banking activities in all scheduled banks and financial institutions.

- Bangladesh Bank can issue an order to ensure separate green banking division in every bank.

- All Bangladeshi banks can follow Bangladesh Bank's policy guidelines regarding school banking.

- School banking can be set as a part of obligatory CSR activities by all banks.

- Every bank should more emphasis on social welfare rather than profitability in case of school banking.

- Every bank should arrange more training and workshop on school banking so that every employee can get clear knowledge about school banking.

- Banks can encourage school authorities to collect tuition fees and other charges through school banking accounts of respective students.

- Banks can arrange different campaign in school premises to understand students about the importance of savings and they can also attract student to open accounts by deliberating some offer and advantages.

- Government should encourage school authorities as well as parents about the importance of savings.

- Scholar should make more research work on school banking.

\section{Conclusion}

In Bangladesh, banks always try to find out more deposit through different products. School banking is a new product issued by almost all banks in Bangladesh directed by Bangladesh Bank. Though it is unknown to someone, the popularity of it is becoming more and more day by day among the school going children and their parents. Private Commercial Banks (PCBs) are the pioneer to create more accounts under this scheme. They have opened about $65 \%$ accounts of total accounts under school banking. Stateowned Commercial Banks (SCBs) and Specialized Development Banks (SDBs) have created a large number of accounts under this scheme. But these progresses are not enough to run smooth school banking operation in Bangladesh. It is satisfactory to say Bangladesh Bank has already issued and is continuously circulating school banking policy guidelines to all scheduled banks. But it is not all duties of Bangladesh Bank regarding school banking. It should monitor and supervise school banking activities of all banks and it can also give an order to all banks to make uniform school banking reporting systems and establish separate school banking division, that will monitor and control school banking activities of that bank.

As present school going children are the future citizen of Bangladesh, so they would be the potential customers of their respective bank. So, for the profit motive banks should encourage students and their parents to go under banking system. Banks can also develop communication with the educational institutions to boost the number of school banking accounts. This may be a social role for the banks to gather scatter, unproductive money from our society to make social deposit for future. This also helps to develop a savings habit among the young children from their early age. That will be a positive sign for our economic development. So, to increase school banking activities in our country, our central bank, all scheduled banks and financial institutions, school going children, parents, educational institutions as well as our government should come forward to set up an environment that facilitates school banking activities in our country to make a financial inclusion across banking system in Bangladesh.

\section{References}

[1] Bangladesh Bank, Quarterly Review Report on School Banking of Banks, Green Banking and CSR Department, Financial Inclusion Wing, Dhaka: Bangladesh Bank, December 2014, September 2014, June 2014, December 2013, June 2013.

[2] Dr. Azizur Rahman Khan, Bank Management: A Fund Emphasis, Dhaka: Brothers Publications, 2009.

[3] Jahidul Alam, School Banking Created a New Era in the Banking Services in Bangladesh, BDOpinion, March 31, 2015. http//www.bdopinion.com/2015/03/31/school-bankingcreated-a-new-era-in-the-banking-servics-inbangladesh/.

[4] Mohammad Ali, School banking getting popularity, Financial Express, VOL 20 NO 314 REGD NO DA 1589, Dhaka, April $23 \quad 2012$. $\mathrm{http} / / \mathrm{www}$. thefinancialexpress-

bd.com/old/more.php?news_id=12543\&date $=2012-04$ 23.

[5] Mohammed Mosroor Hossen, School Banking Scheme as a new Scheme for students, The Daily Frontier, September 22, 2012.http//www.dailyfrontier.com/Frontier/2012015109-

School+Banking + Scheme + as $+\mathrm{a}+$ new + Scheme + for + stu dents + .html.

[6] Oxford Advanced Learner's Dictionary, Eighth Edition 2010, Oxford University Press, New Delhi, India.

[7] Oxford Dictionary of Bussiness, Third Edition 2002, Oxford University Press, New Delhi, India.

[8] Sajjadur Rahman, A new era of school banking, Daily Star, May 12, 2011. http//www.thedailystar.net/newDesign/newsdetails.php?nid=185235.

[9] http://www.dutchbanglabank.com

[10] http://www.ebl.com.bd

[11] http/www.en.m.wikipedia.org/wiki/Bank

[12] http/www.islamibankbd.com

[13] http//www.primebank.com.bd

[14] http//www.rakub.org.bd

[15] http//www.rupalibank.org

[16] http://www.trustbanklimited.com

[17] http//www.uttarabank-bd.com 